\title{
Confirmatory Study of the Multidimensional Scales of Perceived Self-Efficacy with Children ${ }^{*}$
}

\section{Estudio Confirmatorio de las Escalas Multidimensionales de Autoeficacia Percibida con Niños/as}

\author{
Íris M. Oliveira \\ University of Minho, Portugal \\ ORCID: http://orcid.org/0000-0003-4262-6768 \\ Maria do Céu Taveira ${ }^{\mathrm{a}}$ \\ University of Minho, Portugal \\ ORCID: http://orcid.org/0000-0003-1762-8702 \\ ERIK J. PORFELI \\ Northeast Ohio Medical University, Estados Unidos \\ ORCID: http://orcid.org/0000-0001-6482-4971 \\ Randolph C. Grace \\ University of Canterbury, Nueva Zelanda \\ ORCID: http://orcid.org/0000-0003-1115-6089
}

\begin{tabular}{lll}
\hline a Corrrespondence & author. & Email: \\
ceuta@psi.uminho.pt & &
\end{tabular}

How to cite: Oliveira, I. M., Taveira, M. C., Porfeli, E. J., \& Grace, R. C. (2018). Confirmatory Study of the Multidimensional Scales of Perceived SelfEfficacy with Children. Universitas Psychologica, 17(1), 1-12. https://doi.org/10.11144/Javeriana. upsy17-4.csms

\begin{abstract}
The social cognitive career theory suggests that the development of career self-efficacy expectations begins during the childhood period. The Multidimensional Scales of Perceived Self-Efficacy (MSPSE) has been used to assess adolescents and adults' career self-efficacy. This study extends this research by assessing the psychometric characteristics of the MSPSE with children. The MSPSE factorial structure, invariance, and concurrent validity were examined with data from 313 fifth- and sixth-grade girls and boys $\left(M_{\text {age }}=10.8\right)$. Confirmatory factor analyses suggested a good fit of a hierarchical measurement model. Multi-group analyses suggested configurational and metric invariance across grade levels and across gender for the low-order factors. Still, variability in highorder factor loadings was found across gender. The MSPSE was positively correlated with career exploration and academic achievement. This study supports the use of the MSPSE with children, instills future research on children's career self-efficacy, and advances practices promoting career preparedness.

Keywords

career development; career self-efficacy; childhood; measurement; Multidimensional Scales of Perceived Self-Efficacy.
\end{abstract}

\section{RESUMEN}

La Teoría Social Cognitiva del Desarrollo Profesional sugiere que las expectativas de autoeficacia emergen en la infancia. Las Escalas Multidimensionales de Autoeficacia Percibida (EMAP) evalúan la autoeficacia profesional de jóvenes y adultos. Este estudio analiza las propiedades de la EMAP con niños. Su estructura, invariancia factorial 
y validad concurrente fueron analizadas con 313 niños de quinto y sexto grado $(M$ edad $=10.8)$. Los análisis confirmatorios sugirieron buen ajuste de un modelo jerárquico. Los análisis multi-grupo sugirieron invariancia configural y métrica para año escolar y sexo en los factores de primer orden, pero variabilidad en los pesos factoriales del segundo factor de orden para sexo. La EMAP presentó correlaciones positivas y estadísticamente significativas con la exploración profesional y el rendimiento académico. Este estudio sustenta el uso de EMAP con niños. La EMAP puede estimular la investigación sobre la autoeficacia profesional de niños, e incentivar prácticas que los preparen para procesos profesionales futuros.

Palabras clave

autoeficacia profesional; Escalas Multidimensionales de Autoeficacia Percibida; desarrollo profesional; infancia; medición.

Childhood career development is a dynamic and interactional process (Watson, Nota, \& McMahon, 2015), engaging children to consider the future, establish increasing control over their actions, fostering curiosity about work, and building confidence to make choices (Savickas, 2002). Children construct more sophisticated conceptions of career choice and attainment as they progress from concrete to more abstract career reasoning and from fantasy to more realistic precepts of themselves and the environment (Howard \& Walsh, 2010).

Although the Social Cognitive Career Theory, SCCT (Lent, Hackett, \& Brown, 2004) has been mostly employed in adolescence and adulthood, its holds the potential to frame career development research devoted to childhood (e.g., Oliveira, Taveira, Cadime, \& Porfeil, 2016). The SCCT conceives of the elementary and middle school as preparatory years for later career transitions and adjustment to the working world. Such preparation seems relevant considering the rapidly changing nature of the world of work and the pressure to continuously enhance career skills to respond to new career challenges and opportunities (Carneiro, Taveira, Faria, \& Candeias, 2015)Oliveira, do Céu Taveira, Cadime, \& Porfeil, 2015). The SCCT identifies childhood as an important period for experimentation with learning opportunities and development of career self-efficacy and outcome expectations (Lent et al., 2004).
Self-efficacy expectations have been of particular interest to researchers and practitioners in career development (Lent \& Brown, 2013). Self-efficacy expectations are cognitive judgments of a person's prospective capabilities to successfully perform an activity (Lent et al., 2004). Given that self-efficacy expectations are developed in one's learning experiences, they portray the mutual relationships between a person's ongoing experiences, self-representations, and career behaviors (Teixeira, 2009). Self-efficacy influences people's persistence, attribution of academic success to effort/ability, anticipated quality of schoolwork educational and occupational aspirations, career choices and career self-management (Bandura, 2012; Bandura, Barbaranelli, Caprara, \& Pastorelli, 2001; García-Fernandéz et al., 2016; Lent \& Brown, 2013; Pastorelli et al., 2001).

The SCCT suggests that career selfefficacy emerges in childhood (Lent et al., 2004). As children engage in career exploration across academic, leisure, and extracurricular settings, they experiment social learning opportunities (Watson \& McMahon, 2007). These opportunities advance cognitive representations about one's prospective capability to successfully perform similar activities in the future (Lent \& Brown, 2013). Research has supported these assertions by suggesting positive associations between career self-efficacy and career exploration (e.g., Lent, Ezeofor, Morrison, Penn, \& Ireland, 2016; Turner et al., 2006). Longitudinal evidence from childhood through adolescence has also indicated positive associations among career selfefficacy expectations, academic achievement, and the likelihood to continue or drop out of school (Caprara et al., 2008). Moreover, career self-efficacy can affect children's approach or avoidance of activities, which might influence the development of performance percepts and preferences (Bandura et al., 2001). As career selfefficacy is an important antecedent of interests and performance (Lent \& Brown, 2013), it is relevant to address its roots in childhood. 
The Multidimensional Scales of Perceived Self-Efficacy, MSPSE (Bandura, 1990) has been used to assess self-efficacy expectations within the career development field (e.g., Bandura, 2012; Cordeiro \& Lobo, 2016; Lopes \& Teixeira, 2012; Teixeira, 2009). The MSPSE relies on an understanding of the person-context mutual dynamics as the grounding for the development and revision of career self-efficacy expectations. Such a contextually sensitive perspective is aligned with an interactional view of children's career development (Watson et al., 2015) and might, therefore, support its use in childhood.

The original North-American MSPSE version includes 57 items to assess self-efficacy expectations for nine main domains of human functioning -enlisting social resources, academic achievement, self-regulated learning, leisure and extracurricular activities, self-regulation to resist peer pressure, meet others' expectation, engage in social interactions, being self-assertive, and enlisting parental and community supportwith estimates of internal consistency reliability ranging from 0.76 to 0.81 . The MSPSE has been used in several different countries, including all or some of the 57 items depending on the target population and purposes of research. Despite variations in the number of items used, previous studies with high school and college students supported a MSPSE hierarchical factor structure (Choi, Fuqua, \& Griffin, 2001; Miller, Coombs, \& Fuqua, 1999). A hierarchical factor structure has been also suggested in childhood, as extant Hungarian, Italian, and Polish evidence has indicated that children already present a multifaceted and focused representation of selfefficacy expectations and aggregate such facets in general domains of functioning (Pastorelli et al., 2001). Still, "to date, there have been relatively few studies reporting the structure and validity of scores derived from the MSPSE" (Choi et al., 2001, p. 476); hence, calls have been made for additional studies to move from the commonly used exploratory analysis to confirmatory ones that sustain a deepen scientific knowledge of the MSPSE psychometric properties (Choi et al., 2001; Miller et al., 1999; Pastorelli et al., 2001).
Aligned with the MSPSE original version, the Portuguese version (Teixeira \& Carmo, 2004) includes 57 items organized across the nine scales inherent to self-efficacy in different activities, yielding a composite score for the total scale. Previous studies with the Portuguese MSPSE version have relied on exploratory analyses and supported a hierarchical factor structure in seventh-grade, ninth-grade, and college. Internal consistency reliability estimates ranging from 0.76 to 0.89 in seventh-grade, 0.6 to 0.85 in ninth-grade, and 0.62 to 0.84 in college have also been found (Lopes \& Teixeira, 2012; Teixeira, 2008, 2009). Evidence of the MSPSE concurrent validity has been also provided. Research has suggested that self-efficacy expectations for academic success, self-regulated learning, and leisure and extracurricular activities are positively associated with academic achievement, with stronger correlations between academic achievement and self-efficacy for academic success and self-regulated learning than those correlations between self-efficacy for leisure and extracurricular learning (Lopes \& Teixeira, 2012; Teixeira, 2009). Still, a confirmatory study of the Portuguese MSPSE version is needed.

Because the Portuguese MSPSE version has been employed from seventh-grade onward, its utility to assess younger students' career self-efficacy expectations is still unknown. Responding to calls to enrich the assessment of childhood career development (Porfeli, Hartung, \& Vondracek, 2008), this study assesses the capacity of the MSPSE to assess younger students. Considering children's main contexts of career learning and social participation (Lent et al., 2004), we specifically examined the adequacy of the MSPSE scales of self-efficacy expectations for academic success, self-regulated learning, and leisure and extracurricular activities with younger students. Moreover, previous studies have used the MSPSE with girls and boys across different grade levels (Lopes \& Teixeira, 2012; Teixeira, 2009). However, evidence is lacking on the MSPSE factorial invariance for gender and grade levels, specifically in the grade school population in Portugal. 
This study sought to examine the psychometric characteristics of the MSPSE scales with a sample of Portuguese fifth- and sixthgrade girls and boys. The MSPSE factorial structure, invariance for gender and grade levels, and concurrent validity were tested. Based on previous theory and research bearing on the MSPSE, a hierarchical measurement model was expected to yield a good fit to the data (H1). The MSPSE first- and second-order factors were expected to demonstrate acceptable reliability $(\mathrm{H} 2)$. The factor structure was also expected to be invariant for girls and boys and for fifthand sixth-graders (H3). Finally, the MSPSE first- and second-order factors were expected to be positively associated with career exploration (H4) and academic achievement (H5).

\section{Method}

\section{Participants}

This study was approved by the Portuguese General Direction of Education. Participants were recruited through a non-probabilistic intentional sampling method. The sampling criteria enabled the inclusion of fifth and sixth grade children aged 9 to 14 . This age range is aligned with the chronological childhood period in the career development literature (Watson et al., 2015). The sample included 313 children aged 9 to $14(M=10.8, S D=0.86), 137$ (43.8\%) girls and 176 (56.2\%) boys, 150 $(47.9 \%)$ attending fifth-grade and 162 (51.8 $\%)$ attending sixth-grade in one public school of Northwest Portugal. Most of the children were native Portuguese (97\%). Six children were Brazilian, one child was German, one was Portuguese-French, and another child was Portuguese-Venezuelan.

\section{Measures}

Multidimensional Scales of Perceived SelfEfficacy, MSPSE (Bandura, 1990; adapted by Teixeira \& Carmo, 2004)
The self-efficacy expectations for academic success (nine items; e.g., "How easily do you learn mathematics"), self-regulated learning (11 items; e.g., "How easily do you focus on academic contents"), leisure and extracurricular activities (eight items; e.g., "How easily do you learn sports") from the Portuguese MSPSE version were used. Items were answered in a five-point Likert scale from 1 "Not easy at all" to 5 "Very easy." High scores suggested favorable selfefficacy expectations. The items' content was adapted to fifth- and sixth-graders' academic, leisure and extracurricular opportunities (see Appendix 1). Evidence from seventh-graders identified Cronbach's alphas of 0.79, 0.86, and 0.83 for the academic success, self-regulated learning, and leisure and extracurricular scales (Lopes \& Teixeira, 2012).

Childhood Career Exploration Inventory, CCEI (Oliveira, 2016)

The CCEI assesses children's career exploration with 12 items (e.g., "I like to ask my parents about their jobs") answered in a fivepoint Likert scale from 1 "Strongly disagree" to 5 "Strongly agree". Previous studies supported the CCEI factorial invariance for gender and grade levels, and concurrent validity. A Cronbach's alpha of 0.85 was found in this sample.

\section{Procedure}

Informed consent was obtained from the principal, psychologist, teachers, and students' caregivers at the participating school. Children's voluntary participation and confidentiality were assured. In January 2013, two PhD students and a school psychologist collectively administrated the scales of the Portuguese MSPSE version, the CCEI, and additional items eliciting demographic and academic information in the classroom setting. Academic achievement data was obtained through children's self-report of the number of insufficient grades obtained in their last report card. After reverse-scaling data, higher scores were indicative of higher achievement. Children completed the measures within 30 minutes. 


\section{Data analysis}

Data was analyzed with the Analysis of Moment Structures (AMOS), version 20 for Windows. Confirmatory Factor Analyses and multi-group analyses were performed. The analyses were repeated with the Lavaan package in $\mathrm{R}$ (Rosseel, 2012) to verify consistency. The statistical estimates and conclusions were successfully replicated.

Four measurement models were specified: (i) Model 1 followed the three-factor structure of the scales, assuming 28 observed variables and three correlated latent variables; (ii) Model 2 acknowledged that children may not yet differentiate self-efficacy for academic success from self-efficacy for self-regulated learning, thus assuming 28 observed variables and two correlated latent variables; (iii) Model 3 considered that children may not yet cognitively differentiate self-efficacy expectations at all, whereby 28 observed variables and one latent variable were assumed; (iv) Model 4 relied on the factorial structure and composite score suggested by previous studies to specify a hierarchical model with 28 observed variables, three first-order and one second-order latent variables. The errors of measurement were freely estimated and deemed independent across the test of the models. The factor loading of one observed variable was fixed to 1 . Cronbach's alpha was computed.

Missing values ranged from $0 \%$ to $2 \%$, were missing completely at random and were estimated with the mean substitution method. The Mardia's coefficient of multivariate kurtosis was 127.93 with a critical ratio of 27.65 , thus suggesting violation of multivariate normality. Mahalanobis distance values suggested the presence of nine outliers. A non-normal sampling distribution remained when the outliers were filtered. To control for biases derived from the multivariate non-normality, the Maximum Likelihood (ML) estimation method with bootstrapping was used (Gilson et al., 2013). The analyses were run with and without outliers to control for their possible influential effect (e.g., Pinto, Taveira, Candeias, \& Araújo 2013).
Model fit was evaluated with the BollenStine chi-square goodness-of-fit test $\left(\chi^{2}\right)$ with 500 bootstrap samples (Gilson et al., 2013), the chi-square to degrees of freedom ratio $(\chi$ $2 / d f)$, the Comparative Fit Index (CFI), the Tucker-Lewis Index (TLI), and the Root Mean Square Error of Approximation (RMSEA) with $90 \%$ confidence intervals (CI). Values of $\chi$ $2 /$ df lower than 3 and lower than 2 respectively indicated acceptable and good fit (Blunch, 2008; Kline, 2011). Values of CFI and TLI ranging from 0.9 to 0.95 and of RMSEA ranging from 0.05 to 0.08 were deemed acceptable (Jackson, Gillapsy, \& Purc-Stephenson, 2009). As four measurement models were compared, the Akaike Information Criterion (AIC) was also used for model selection, with lower AIC values indicating better fit (ibid.).

Configurational and metric invariance for gender and grade levels were tested. Sub-model 0 tested configurational invariance by checking whether the factorial model yielded a good fit to the data of girls, boys, fifth- and sixth-graders separately. Sub-model 1 tested the baseline fit across the combined groups. Sub-model 2 tested the metric invariance while constraining the measurement weights to be invariant across groups. If the hierarchical model was used in multi-group analyses, two levels of metric invariance would be examined (Chen, Sousa, \& West, 2005). Metric invariance was evaluated in terms of CFI and RMSEA differences $(\Delta): \Delta$ CFI $(>-0.01)$ and $\triangle$ RMSEA $<(0.05)$ (Cheung $\&$ Rensvold, 2002).

As the CCEI and academic achievement data were non-normally distributed, parametric and non-parametric correlation coefficients (i.e., Pearson and Spearman) were computed. Parametric results were reported when similar conclusions were found (Fife-Schaw, 2006).

\section{Results}

The results with and without outliers suggested that Model 3 yielded the poorest fit to the data. The other models yielded similar fit results relative to each another (see Table 1 ). 
Table 1

Fit statistics for the specified measurement models

\begin{tabular}{|c|c|c|c|c|c|c|}
\hline Model & $\chi^{2 / d f}$ & Bollen-Stine $p$ value & CFI & TLI & RMSEA $(90 \% \mathrm{CI})$ & AIC \\
\hline \multicolumn{7}{|c|}{ With outliers } \\
\hline Model 1 & 3.09 & $* * *$ & 0.84 & 0.82 & $0.08(0.08-0.09)$ & 1189.91 \\
\hline Model 2 & 3.19 & $* * *$ & 0.83 & 0.82 & $0.08(0.08-0.09)$ & 1229.52 \\
\hline Model 3 & 3.52 & *** & 0.8 & 0.79 & $0.09(0.08-0.1)$ & 1342.52 \\
\hline Model 4 & 3.24 & ** & 0.83 & 0.82 & $0.08(0.08-0.09)$ & 1299.52 \\
\hline \multicolumn{7}{|c|}{ Without outliers } \\
\hline Model 1 & 2.94 & **** & 0.85 & 0.84 & $0.08(0.07-0.09)$ & 1139.74 \\
\hline Model 2 & 3.06 & $* * *$ & 0.84 & 0.83 & $0.08(0.08-0.09)$ & 1182.5 \\
\hline Model 3 & 3.43 & $* * *$ & 0.82 & 0.8 & $0.09(0.08-0.1)$ & 1310.89 \\
\hline Model 4 & 3.11 & ** & 0.85 & 0.83 & $0.08(0.08-0.09)$ & 1253.23 \\
\hline
\end{tabular}

As none of the models conformed to the referenced values for the goodness-of-fit indexes, additional modifications were considered. The Bollen-Stine bootstrap chi-square was improved for all models if the errors associated with items 21 and 28 were deleted. It seemed reasonable to eliminate these items due to the statistical fit advantages and acknowledging that their content seemed redundant for children. Model fit without these items was re-evaluated, absent outliers given their slight adverse effect on model fit (see Table 2).

\section{Table 2}

Fit statistics for the specified measurement models without items 21 and 28

\begin{tabular}{|c|c|c|c|c|c|c|}
\hline Model & $\chi^{2 / d f}$ & Bollen-Stine $p$ value & CFI & TLI & RMSEA $(90 \% \mathrm{CI})$ & AIC \\
\hline Model 1 & 2.47 & $* * *$ & 0.9 & 0.89 & $0.07(0.06-0.08)$ & 840.94 \\
\hline Model 2 & 2.53 & $* * *$ & 0.89 & 0.83 & $0.07(0.07-0.08)$ & 859.69 \\
\hline Model 3 & 3.26 & **** & 0.84 & 0.83 & $0.09(0.08-0.09)$ & 1079.81 \\
\hline Model 4 & 2.47 & $* * *$ & 0.9 & 0.89 & $0.07(0.06-0.08)$ & 840.94 \\
\hline
\end{tabular}

Results without items 21 and 28 suggested that Model 3 continued to yield the worst fit compared to other models. Models 1 and 4 presented similar results. These models conformed to the referenced values for the goodness-of-fit indexes and presented the lowest AIC value. Although the fits of Models 1 and 4 were similar, the latter was preferred due to its hierarchical nature. A hierarchical measurement model holds the advantage of greater flexibility in further data analyses and parsimony in explaining the covariances among first-order factors (Chen et al., 2005), which are offered in Table 3.
Table 3

First-order factors correlation coefficients

\begin{tabular}{lrrr}
\hline MSPSE scales & \multicolumn{1}{c}{ SEAS } & SESRL & SELEA \\
\hline SEAS & 1 & & \\
SESRL & $0.82 * * *$ & 1 & \\
SELEA & $0.69 * * *$ & $0.72 * * *$ & 1 \\
\hline
\end{tabular}

Note.SEAS, SESRL, SELEA = self-efficacy
for academic success, self-regulated learning,
leisure and extracurricular activities. Results
are presented without outliers. $* * * p<0.001$.

The standardized regression weights were all statistically significant $(p<0.001)$. In the first-order factors, the standardized regression weights ranged from 0.36 to 0.77 in self-efficacy expectations for academic success, 0.5 to 0.84 in self-efficacy expectations for self-regulated learning, and 0.39 to 0.85 in self-efficacy expectations for leisure and extracurricular activities. The standardized regression weights ranged from 0.84 to 0.96 in the secondorder factor labeled self-efficacy expectations for academic, leisure, and extracurricular activities (see Figure 1).

Acceptable reliability was found for the firstand second-order factors: 0.85 in self-efficacy for academic success; 0.92 in self-efficacy for self-regulated learning; 0.8 in self-efficacy for leisure and extracurricular activities; and 0.95 in the second-order factor. The results with and without outliers consistently suggested that the hierarchical model yielded an acceptable fit for girls and boys, fifth- and sixth-graders (see Table 4). All the measurement weights were statistically significant $(p<0.001)$. Because the results with outliers were generally worse, the remaining analyses were run absent outliers.

Table 4

Configurational and baseline models for gender and grade levels

\begin{tabular}{|c|c|c|c|c|c|}
\hline Model & $\chi^{2} / d f$ & Bollen-Stine $p$ value & CFI & TLI & RMSEA $(90 \% \mathrm{CI})$ \\
\hline \multicolumn{6}{|l|}{ With outliers } \\
\hline Sub-model 0 Girls & 1.81 & $* * *$ & 0.87 & 0.86 & $0.08(0.07-0.09)$ \\
\hline Sub-model $0_{\text {Boys }}$ & 2.04 & $* * *$ & 0.87 & 0.86 & $0.08(0.07-0.09)$ \\
\hline Sub-model 0 5th-graders & 1.99 & $* * *$ & 0.84 & 0.83 & $0.08(0.07-0.09)$ \\
\hline Sub-model 0 Gth-graders & 1.82 & $* * *$ & 0.9 & 0.89 & $0.07(0.06-0.08)$ \\
\hline Sub-model 1 con & 1.93 & $* * *$ & 0.87 & 0.86 & $0.06(0.05-0.06)$ \\
\hline Sub-model $1_{\mathrm{Co}}$ & 1.91 & **** & 0.87 & 0.86 & $0.05(0.05-0.06)$ \\
\hline Withou & & & & & \\
\hline 0 Girls & 1.87 & **** & 0.89 & 0.88 & $-0.08)$ \\
\hline Sub-n & 1.87 & *** & 0.89 & 0.88 & $0.07(0.06-0.08)$ \\
\hline 10 sth-rraders & 1.79 & **** & 0.88 & 0.87 & $0.07(0.06-0.08)$ \\
\hline 10 th-graders & 1.79 & **** & 0.90 & 0.89 & $0.7(0.06-0.08)$ \\
\hline Sub-m & 1.81 & $* * *$ & 0.89 & 0.88 & $0.05(0.05-0.06)$ \\
\hline Sub-model $1_{\text {Combined grade levels }}$ & 1.79 & $* * *$ & 0.89 & 0.88 & $0.05(0.05-0.06)$ \\
\hline
\end{tabular}


Figure 1

MSPSE modified Model 4 estimates

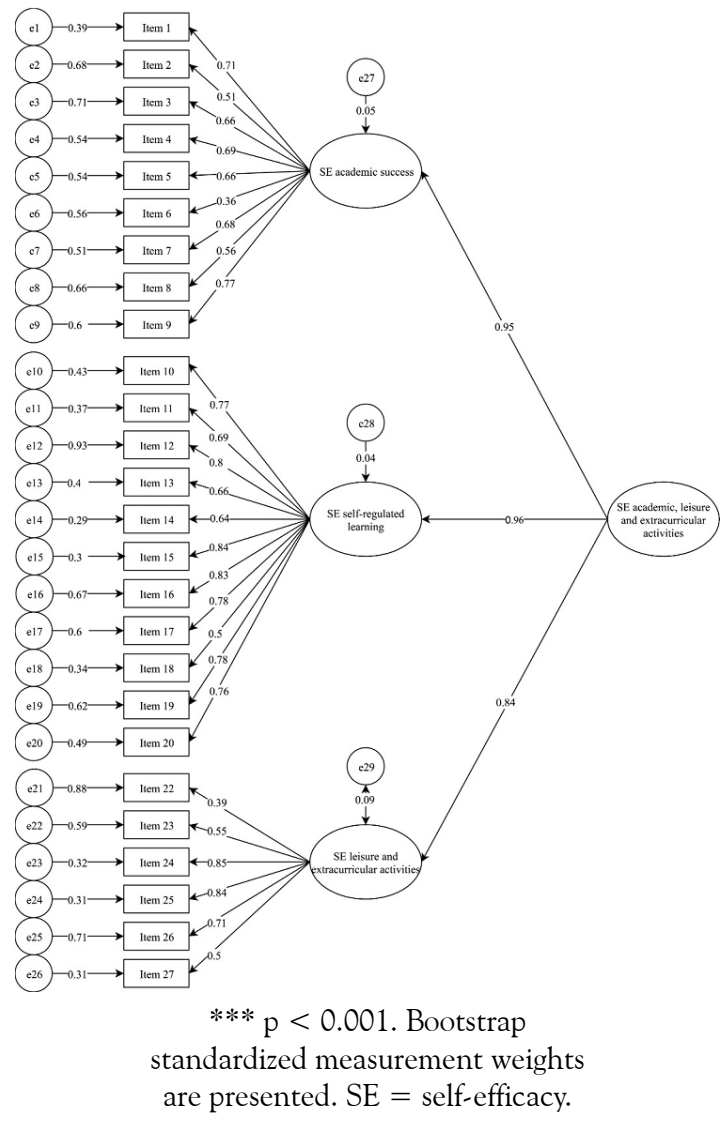

Comparison of sub-models 1 and 2 suggested metric invariance of the first-order factors across gender and grade levels. Metric invariance of the second-order factor was also found for grade levels but not for gender (see Table 5). Girls presented higher average standardized measurement weights for the second-order factor than boys (see Figure 2).

\section{Table 5}

Metric invariance for gender and grade levels

\begin{tabular}{|c|c|c|c|c|c|c|c|}
\hline Model & $\chi^{2} / d f$ & Bollen-Stine $p$ value & CFI & TLI & RMSEA $(90 \% \mathrm{CI})$ & CFI & RMSEA \\
\hline Gender & & & & & & & \\
\hline Sub-model 1 & 1.81 & $* * *$ & 0.89 & 0.88 & $0.05(0.05-0.06)$ & & \\
\hline Sub-model 2 L1 & 1.78 & $* * *$ & 0.89 & 0.88 & $0.05(0.05-0.06)$ & 0.001 & 0.001 \\
\hline $\begin{array}{l}\text { Sub-model } 2 \mathrm{~L} 2 \\
\text { Grade levels }\end{array}$ & 1.96 & $* * *$ & 0.86 & 0.87 & $0.06(0.05-.06)$ & 0.03 & -0.005 \\
\hline Sub-model 2 & 1.79 & $* * *$ & 0.88 & 0.89 & $0.05(0.05-0.06)$ & & \\
\hline Sub-model 2 L1 & 1.76 & $* * *$ & 0.89 & 0.89 & $0.05(0.05-0.06)$ & 0.001 & 0.001 \\
\hline Sub-model 2 L2 & 1.79 & $* * *$ & 0.88 & 0.88 & $0.05(0.05-0.06)$ & 0.009 & 0.001 \\
\hline
\end{tabular}

Note.L1 and L2 = Levels 1 and 2 (i.e., firstand second-order factors). $* * * \mathrm{p}<0.001$
Figure 2

MSPSE modified Model 4 estimates for gender

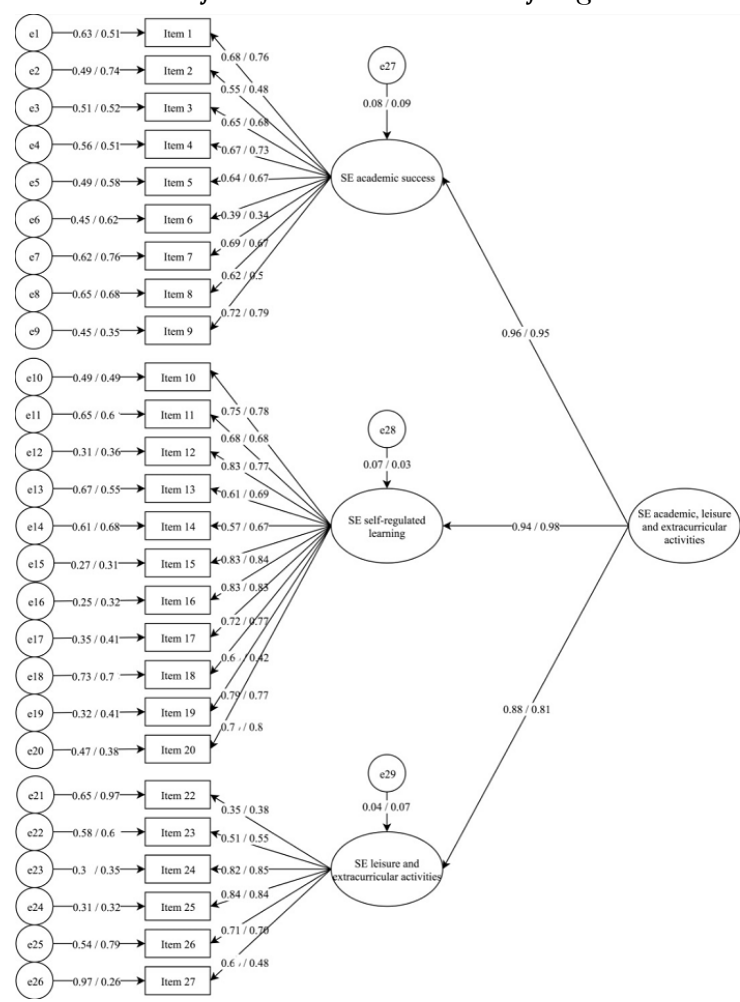

Bootstrap standardized regression coefficients presented. Estimates for girls and boys respectively depicted on the left and right sides.

The MSPSE first- and second-order factors were positively and statistically significantly correlated with career exploration and academic achievement (see Table 6).

\section{Table 6}

Correlations of the MSPSE scores with career exploration and academic achievement

\begin{tabular}{lrrrr}
\hline \multicolumn{1}{c}{ Correlations } & \multicolumn{1}{c}{ SEAS } & \multicolumn{1}{c}{ SESRL } & SELEA & Total MSPSE \\
\hline Career exploration & $0.15^{*}$ & $0.31^{* * *}$ & $0.34^{* * *}$ & $0.29^{* * *}$ \\
Academic achievement & $0.55^{* *}$ & $0.52 * *$ & $0.33^{* *}$ & $0.53 * *$
\end{tabular}

Note.SEAS, SESRL, SELEA = selfefficacy for academic success, self-regulated learning, leisure and extracurricular activities. $* * p<0.01$. $* * * p<0.001$.

\section{Discussion}

This study examined the psychometric properties of the MSPSE with Portuguese children. The results suggest that the MSPSE is reliable and 
demonstrates concurrent validity when modeled as a hierarchical set of constructs and used with children.

This study found that the psychometric properties of the instrument improved by eliminating two items. The content of these items seemed redundant, which suggest that fifth- and sixth-grader children may struggle to discriminate the differences between these items. Further research employing techniques based on Item Response Theory (e.g., Oliveira et al., 2016) could offer a complementary evaluation of these items in the assessment of children's self-efficacy expectations for leisure and extracurricular activities.

Results also suggested that the measurement model specifying a general career self-efficacy construct yielded the poorest fit to the data while the model specifying a hierarchical factorial structure yielded acceptable fit and reliability, thus supporting $\mathrm{H} 1$ and $\mathrm{H} 2$. The hierarchical measurement model is aligned with previous North-American, Eastern, and Western European studies of the MSPSE (e.g., Choi et al., 2001; Miller et al., 1999; Pastorelli et al., 2001; Teixeira, 2009). It also supports the view that children progress from a concrete and less differentiated career reasoning to a more abstract and differentiated one (Howard \& Walsh, 2010). Particularly, children as young as fifthand sixth-grade maintain a more differentiated understanding of career aspects (Howard \& Walsh, 2010; Lent et al., 2004) and cognitively represent self-efficacy expectations for both specific and general domains of functioning (Pastorelli et al., 2001) inherent to first- and second-order factors. In addition, the estimates of internal consistency reliability found in this study were generally higher than the estimates reported in previous studies (e.g., Bandura, 1990; Lopes \& Teixeira, 2012; Teixeira, 2008, 2009), which supports the use of the MSPSE with Portuguese children attending fifth- and sixthgrade.

This study also offered evidence of the MSPSE factorial invariance for gender and grade levels, which has been lacking in previous studies of the MSPSE. Results suggested that the MSPSE first-order factors are invariant for girls, boys, fifth-, and sixth-graders. This finding extends the use of the MSPSE from seventh-grade, ninth-grade, and college students (e.g., Lopes \& Teixeira, 2012; Teixeira, 2009) to fifth- and sixthgrade girls and boys. Still, the MSPSE secondorder factor was equivalent for grade levels, but not for gender. Partial factorial invariance was found for gender, thus offering partial support for $\mathrm{H} 3$. These findings suggest that care should be taken when employing the secondorder factor with girls and boys, as variability might occur in the measurement loadings. This might indicate differences for girls and boys in cognitive representations of career activities. As girls presented higher average loadings for the second-order factor than boys, then girls might hold a stronger cognitive representation of the construct relative to boys. Still, further studies should examine the potential of the MSPSE to determine if and how measurement aspects could be enhanced to yield an equivalent measure for girls' and boys' self-efficacy expectations for academic, leisure, and extracurricular activities.

Evidence supported $\mathrm{H} 4$ and H5. The association between self-efficacy expectations and career exploration is consistent with the previous literature (e.g., Lent et al., 2016; Turner et al., 2006). Further research could test the joint role of career self-efficacy expectations and career exploration in children's approach or avoidance of activities (Lent et al., 2004). It is noteworthy that self-efficacy for self-regulated learning and for leisure and extracurricular activities were strongly related with career exploration. This suggests that career exploration is more akin to self-regulated learning and more aligned with extracurricular activities. Future research could explore if and how educational models promoting self-regulated learning (e.g., problem-based and project-based learning) and extracurricular activities could be employed to promote career exploration and how career development activities could promote selfregulated learning and extracurricular pursuits. In addition, the results associating the MSPSE scores with academic achievement are aligned with MSPSE research with older students (Lopes 
\& Teixeira, 2012; Teixeira, 2009) and SCCT assertions (Lent \& Brown, 2013). Self-efficacy expectations for academic success and selfregulated learning were strongly correlated with academic achievement, which is consistent with evidence derived from older students (Cordeiro \& Lobo, 2016; Lopes \& Teixeira, 2012; Teixeira, 2009). Future research could further explore and test how relations among career self-efficacy and academic achievement vary for children who are more/less engaged in school or who do/do not benefit from additional educational services (Lopes \& Teixeira, 2012; Watson et al., 2015).

Future research should expand evidence of the MSPSE concurrent validity. For example, the associations between children's career self-efficacy expectations, career outcome expectations, and interests could be investigated, thus testing SCCT postulates with younger individuals (Lent et al., 2004). The MSPSE predictive validity could also be tested with longitudinal data assessing if and how selfefficacy for academic, leisure, and extracurricular activities during childhood affect academic and career processes in that same period and later in the lifespan (Bandura et al., 2001; Caprara et al., 2008; García-Fernández et al., 2016).

This study is situated within the literature supporting the implementation of early career practices aimed at promoting children's preparedness for later career transitions and adjustment. These practices contribute to a developmental model of preparing children to cope with societal and career challenges (Carneiro et al., 2015; Pastorelli et al., 2001). Such early career practices could facilitate children's development toward favorable career self-efficacy beliefs and prevent an early foreclosure of career options based on negative self-efficacy (Bandura, 2012; Lent et al., 2004). The use of the MSPSE with children could also strengthen the evaluation of impact of these practices.

Some limitations of this study should be noted. Although we focused on the psychometric features of the Portuguese MSPSE version with children, the data was sourced from a sample from Northwest Portugal. It would be useful for future research to replicate this study with a larger sample of children living in different regions of Portugal. Including a larger and more diverse sample of Portuguese children would also facilitate establishing norms to help understand how individual children compare to a representative population and specifically identifying pupils who could benefit the most from practices fostering favorable career self-efficacy expectations. Another limitation involves a reliance on self-reported information from children. Future research could extend the focus to key informants like teachers and parents to discern if and how the results vary across groups.

In conclusion, this study advanced previous efforts to examine the psychometric properties of the MSPSE (Choi et al., 2001) and to validate the measure to Portugal (Teixeira, 2009) by offering confirmatory results and evidence of its applicability to children. Our findings support the use of three MSPSE scales to assess children's self-efficacy expectations for academic, leisure, and extracurricular activities. This study also informs the use of the MSPSE scales with both genders and grade levels. The results support the possibility of using either scale or composite scores in assessments with fifth- and sixthgraders, but recommend the use of scale scores with girls and boys. Additionally, the MSPSE may support future research investigating children's career exploration and academic achievement. This study yields further support for the SCCT model during childhood and sustains the inclusion of career self-efficacy in practices that promote children's academic achievement and preparedness for later career transitions and adjustment (Lent et al., 2004).

\section{References}

Bandura, A. (1990). Multidimensional scales of perceived academic efficacy. Stanford, CA: Stanford University.

Bandura, A. (2012). On the functional properties of perceived self-efficacy revisited. Journal 
of Management, 38(1), 9-44. https://doi.org /10.1177/0149206311410606

Bandura, A., Barbaranelli, C., Caprara, G., \& Pastorelli, C. (2001). Self-efficacy beliefs as shapers of children's aspirations and career trajectories. Child Development, 72(1), 187-206. https://doi.org/10.1111/14 $67-8624.00273$

Blunch, N. (2008). Introduction to structural equation modelling using SPSS and AMOS. Thousand Oaks, California: Sage Publications.

Carneiro, J., Taveira, M. C., Faria, L., \& Candeias, A. (2015). Social competence and career development: validation of a scale with secondary students Universitas Psychologica, 14(3), 889-898. http://dx.doi. org/10.11144/Javeriana.upsy14-3.sccd

Caprara, G. V., Fida, R., Vecchione, M., Del Bove, G., Vecchio, G. M., Barbaranelli, C., \& Bandura, A. (2008). Longitudinal analysis of the role of perceived self-efficacy for self-regulated learning in academic continuance and achievement. Journal of Educational Psychology, 100(3), 525-534. ht tps://doi.org/10.1037/0022-0663.100.3.525

Chen, F. F., Sousa, K. H., \& West, S. G. (2005). Teacher's corner: Testing measurement invariance of secondorder factor models. Structural Equation Modeling: A Multidisciplinary Journal, 12(3), 471-492. https://doi.org/10.1207/s1532800 7sem1203_7

Cheung, G. W., \& Rensvold, R. B. (2002). Evaluating goodness-of-fit indexes for testing measurement invariance. Structural Equation Modeling: A Multidisciplinary Journal, 9(2), 233-255. https://doi.org/10.1 207/S15328007SEM0902_5

Choi, N., Fuqua, D., \& Griffin, B. (2001). Exploratory Analysis of the Structure of Scores from the Multidimensional Scales of Perceived Self-Efficacy. Educational and Psychological Measurement, 61 (3), 475-489.

Cordeiro, S., \& Lobo, C. C. (2016). Self-efficacy and academic adaptation: Contributions to promote psychological adjustment. Human
Frontier Science Program Journal, 10(1), $1-10$.

Fife-Schaw, C. (2006). Levels of measurement. In G. M. Breakwell, S. Hammond, C. FifeSchaw, \& J. A. Smith (Eds.), Research methods in psychology (pp. 50-63). London: Sage.

García-Fernández, J. M., Inglés-Saura, C. J., Vicent, M., Gonzálvez, C., Martín, N. L., \& Pérez-Sánchez, A. M. (2016). Relación entre autoeficacia y autoatribuciones académicas en estudiantes chilenos. Universitas Psychologica, 15(1), 79-88. https: //doi.org/10.11144/Javeriana.upsy15-1.raaa

Gilson, K. M., Bryant, C., Bei, B., Komiti, A., Jackson, H., \& Judd, F. (2013). Validation of the Drinking Motives Questionnaire (DMQ) in older adults. Addictive Behaviors, 38(5), 2196-2202. https://doi.org/10.1016/j .addbeh.2013.01.021

Howard, K., \& Walsh, M. (2010). Conceptions of career choice and attainment: Developmental levels in how children think about careers. Journal of Vocational Behavior, 76(2), 143-152. https://doi.org/10.1016/j.jv b.2009.10.010

Jackson, D. L., Gillaspy, J. A., \& PurcStephenson, R. (2009). Reporting practices in confirmatory factor analysis: An overview and some recommendations. Psychological Methods, 14(1), 6-23. https://d oi.org/10.1037/a0014694

Kline, R. B. (2011). Principles and practice of structural equation modeling. New York, NY: The Guilford Press.

Lent, R. W., \& Brown, S. D. (2013). Social cognitive model of career self-management: Toward a unifying view of adaptive career behavior across the lifespan. Journal of Counseling Psychology, 60(5), 557-568. https://doi.org/10.1037/a0033446

Lent, R. W., Ezeofor, I., Morrison, M. A., Penn, L. T., \& Ireland, G. W. (2016). Applying the social cognitive model of career self-management to career exploration and decision-making. Journal of Vocational Behavior, 93, 47-57. https://doi.org/10.1016 /j.jvb.2015.12.007 
Lent, R. W., Hackett, G., \& Brown, S. D. (2004). Una perspectiva social cognitiva de la transición entre la escuela y el trabajo. Evaluar, 4, 1-22.

Lopes, A. R., \& Teixeira, M. O. (2012). Projetos de carreira, autoeficácia e sucesso escolar em ambiente multicultural. Revista Brasileira de Orientação Profissional, 13(1), 7-14.

Miller, J. W., Coombs, W. T., \& Fuqua, D. R. (1999). An examination of psychometric properties of Bandura's multidimensional scales of perceived self-efficacy. Measurement and Evaluation in Counseling and Development, 31(4), 186-196.

Oliveira, I. M. (2016). Construction and validation of the childhood career exploration inventory (Doctoral dissertation). School of Psychology, University of Minho, Portugal.

Oliveira, I. M., Taveira, M. C., Cadime, I., \& Porfeli, E. J. (2016). Psychometric properties of a career exploratory outcome expectations measure. Journal of Career Assessment, 24(2), 380-396. https://doi.org/ $10.1177 / 1069072715580577$

Oliveira, Í. M., do Céu Taveira, M., Cadime, I., $\&$ Porfeli, E. (2008). Children's vocational development: A research rationale. The Career Development Quarterly, 57(1), 25-37. https://doi.org/10.1002/j.2161-0045 .2008.tb00163.x

Pastorelli, C., Caprara, G. V., Barbaranelli, C., Rola, J., Rozsa, S., \& Bandura, A. (2001). The structure of children's perceived selfefficacy: A cross-national study. European Journal of Psychological Assessment, 17, 87-97. https://doi.org/10.1027//1015-5759. 17.2.87

Pinto, J. C., Taveira, M. C., Candeias, A., \& Araújo, A. M. (2013). Análise fatorial confirmatória da Prova de Avaliação de Competência Social Face à Carreira. Psicologia: Reflexão e Crítica, 26(3), 469-478. http://doi.org/10.1590/S0102-797 22013000300006

Porfeli, E. J., Hartung, P. J., \& Vondracek, F. W. (2008). Children's vocational development: A research rationale. The Career Development Quarterly, 57(1), 25-37. http://doi.org/10.1002/j.2161-0045. 2008.tb00163.x

Rosseel, Y. (2012). Lavaan: An R package for structural equation modeling. Journal of Statistical Software, 48(2), 1-35. https://doi. org/10.18637/jss.v048.i02

Savickas, M. L. (2002). Career construction: A developmental theory of vocational behavior. In D. Brown (Ed.), Career choice and development (pp. 149-205). San Francisco, CA: Jossey Bass.

Teixeira, M. O. (2008). A escala multidimensional de autoeficácia percebida: Um estudo exploratório numa amostra de estudantes do ensino superior. Revista Iberoamericana de Diagnóstico y Evaluación Psicologica, 25(1), 141-157.

Teixeira, M. O. (2009). Uma medida de autoeficácia percebida em contextos sociais e académicos. Psychologica, 51, 47-55.

Teixeira, M. O., \& Carmo, A. M. (2004). Estudos com a versão portuguesa da Escala Multidimensional de Autoeficácia Percebida de Bandura (MSPSE). In C. Machado, L. Almeida, M. Gonçalves, \& V. Ramalho (Eds.), Avaliação psicológica: Formas e contextos (pp. 198-203). Braga, Portugal: Psiquilibrios.

Turner, S. L., Trotter, M. J., Lapan, R. T., Czajka, K. A., Yang, P., \& Brissett, A. E. (2006). Vocational skills and outcomes among native American adolescents: $A$ test of the integrative contextual model of career development. The Career Development Quarterly, 54(3), 216-226. https://doi.org/1 0.1002/j.2161-0045.2006.tb00153.x

Watson, M., \& McMahon, M. (2007). Children's career development learning: A foundation for lifelong career development. In $\mathrm{V}$. B. Skorikov, \& W. Patton (Eds.), Career development in childhood and adolescence (pp. 29-45). Rotterdam, Netherlands: Sense Publishers.

Watson, M., Nota, L., \& McMahon, M. (2015). Evolving stories of child career development. International Journal for 
Educational and Vocational Guidance, 15(2), 175-184. https://doi.org/10.1007/s10775-0 $15-9306-6$
Partnership Agreement (POCI-01-0145FEDER-007653).

\section{Appendix 1}

\section{MSPSE administrated items}

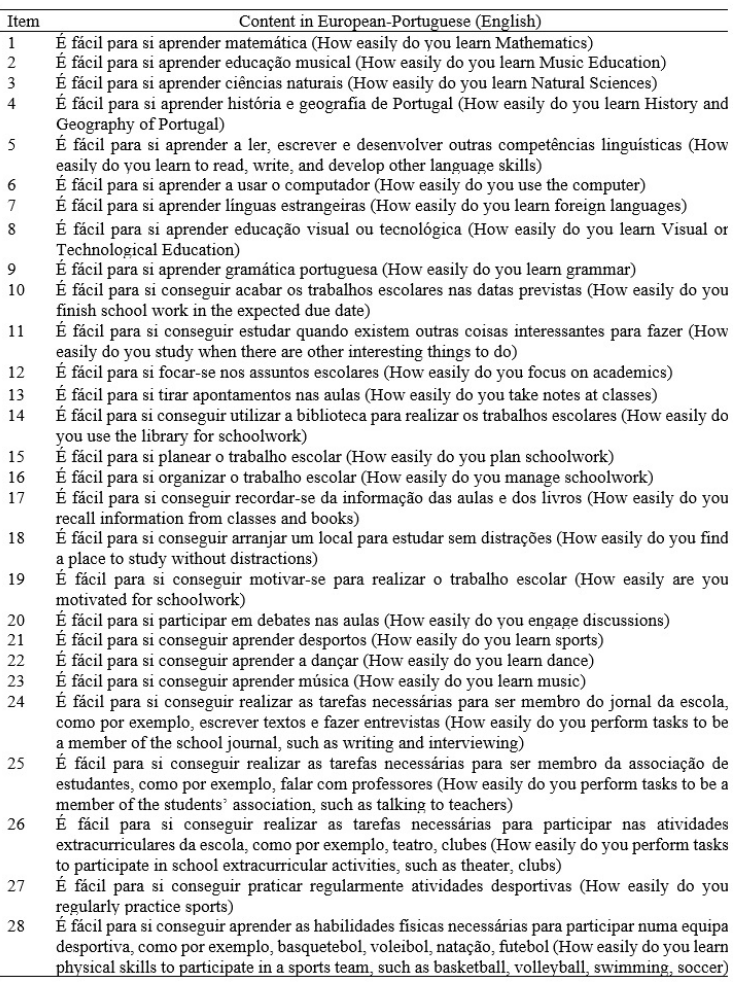

Notes

* Research article. This work was funded by the Portuguese Foundation for Science and Technology through the Doctoral grant SFRH/BD/84162/2012, supported by national funds of the Ministry of Education and Science and the European Social Fund through the Human Capital Operational Program. This study was conducted at Psychology Research Centre (UID/ PSI/01662/2013), University of Minho, and supported by the Portuguese Foundation for Science and Technology and the Portuguese Ministry of Education and Science through national funds and co-financed by FEDER through COMPETE2020 under the PT2020 